\title{
Fate of Fenitrothion in Eel Gills
}

\author{
Encarna SANCHO, Dolores FerRANDO, Miguel GAMON* and Enrique ANDrEU \\ Laboratory for Ecotoxicology, Department of Animal Biology, University of Valencia, Dr. Moliner 50, \\ E-46100 Burjasot, Valencia, Spain \\ *Agrarian Laboratory, Conselleria de Agricultura, Generalitat Valenciana, Spain
}

(Received December 1, 1997; Accepted April 13, 1998)

\begin{abstract}
Eels of species Anguilla anguilla were exposed to sublethal concentrations of fenitrothion in a flow-through test system. Bioaccumulation and elimination of the toxicant in the branchial tissue of the eels were studied. Steady-state was reached after $48 \mathrm{hr}$ of exposure to $0.02 \mathrm{ppm}$ of toxicant, and earlier ( 24 $\mathrm{hr}$ ) exposed to $0.04 \mathrm{ppm}$. Steady-state was maintained until the end of the exposure in both experiments. The highest bioconcentration factor (BCF) value was calculated in animals exposed to $0.04 \mathrm{ppm}$ of toxicant, showing the relationship between the bioconcencentration into gills and the water disponibility. When the animals were transferred to clean water (depuration phase) they showed a rapid tendency to eliminate the pesticide. Pharmaco-kinetics parameters for fenitrothion in eel gills $\left(K_{1}, K_{1}\right.$ and $\left.T_{1 / 2}\right)$ were calculated. They showed relatively low $K_{2}\left(0.0014\right.$ and $\left.0.029 \mathrm{hr}^{-1}\right)$ and higher half-lives. Paralelly, total protein content in the gills was monitored during exposure and depuration phases. A depletion of total proteins of a $70 \%$ was observed in gill tissue at the end of the pesticide exposure. Although a tendency to recover protein levels was observed during the depuration phases, the depletion was maintained until the end of the experiments. The results showed a stress situation as a consequence of fenitrothion exposure which indicates the use of proteins as response to the increased energy requirements in this tissue.
\end{abstract}

\section{INTRODUCTION}

It is often assumed that bioconcentration of organophosphate insecticides (OP) poses no risk for the ecosystem. Exposures, if they occur, would almost invariabily be sublethal concentrations of pesticide. However, a number of physiological and behavioral responses can have a direct bearing on the survival and/or reproductive potential of individuals of a species. The significance of these effects is the latitude with which any level of exposure can be interpreted.1) Any of these effects can influence the ability of species to adapt and respond to other environmental stresses and community interactions. An important part of predicting accumulation is understanding and quantifying the exchange of organic chemicals across fish gills. Gill epithelium is the dominant site of gas exchange, ionic-regulation, acid-base balance, and nitrogenous waste excretion for fishes, thereby serving a multitude of vital functions for these aquatic animals. It represents the major portion of the body surface area of fish and also presents only at 5 to $10 \mu \mathrm{m}$ barrier between water and blood ${ }^{2)}$ consequently most of the chemical transferred between the fish and the environment occurs across the gills. The possibility exits that agricultural use of a pesticide or animai health product could result in introduction of the agent to nearby bodies of water, leading to exposure of aquatic organisms. Numerous chemicals have been found to bioconcentrate in the aquatic organisms. ${ }^{3)}$ The extent to which an organic compound may accumulate in aquatic organisms such as fish is often predicted to assess the potential of a compound to be present in the associated food chain.

Fenitrothion is employed mainly for elimination of rice stem bores and due to its low persistence in aquatic environment. $\left.{ }^{4}\right)$ Sublethal levels of fenitrothion $(0.02 \mu \mathrm{l} /$ l) have been found in water-ways following spray operations. $^{4,5)}$ Since normal organic constituents acts as the key substrates for intermediary metabolism, a study of these compounds is essential to understand the changes brought about by the treatment with pesticides. Lipid and protein metabolism, tissue glycogen and glucose and lactate blood levels are usually altered after exposure to a pesticide and can be used as good indicators of low pollutant levels in the aquatic environment.

To assess the bioconcentration of fenitrothion by a fish, a dynarnic study was undertaken using the european eel (Anguilla anguilla). Specifically, the uptake and depuration of fenitrothion by gill eel tissue were measured to determine the corresponding rate constants and 
the steady-state bioconcentration factor (BCF), total proteins in gill tissue were also estimated.

\section{MATERIALS AND METHODS}

\section{Test Chemical}

Technical grade fenitrothion [O,O-dimethyl-O-(4- $m$ tolyl) phosphorothioate] ( $96 \%$ of purity) was purchased from AFRASA Company (Spain). Two sublethal test concentrations $(0.04$ and $0.02 \mathrm{mg} / l)$ used for this study were based on $96-\mathrm{hr}$ static $\mathrm{LC}_{50}(0.2 \mathrm{mg} / l)$ values of this insecticide for $A$. anguilla. ${ }^{6}$

\section{Test Animals}

Individuals of $A$. anguilla (flesh weight, 20-30 g; length, 16-20 cm) were collected from Albufera Lake (Valencia, Spain). They were acclimatized to laboratory conditions for one week in $300 l$ glass tanks before the start of the experiments. The tanks were supplied with a continuous flow of tap water (temperature: $20 \pm$ $2^{\circ} \mathrm{C}$; total hardness: $240 \pm 10 \mathrm{ppm}$ as $\mathrm{CaCO}_{3}$ according to the Merck classification, Aquamerck ${ }^{\circledR} 8039$; pH: $7.9 \pm 0.2$ using a Crison $\mathrm{pH}$ meter ${ }^{\circledR}$; alkalinity: $4.1 \pm 0.5 \mathrm{mmol} / \mathrm{l}$, Aquamerck ${ }^{\circledR} 11109$, Germany). A 12-hr photoperiod (light on from 8.0 to $20.0 \mathrm{hr}$ ) was maintained. Eels did not respond to feeding attempts in our laboratory, but all animals were healthy. ${ }^{6)}$ No mortality was observed during the acclimation period.

\section{Test System}

Experiments were carried out in a continuous flowthrough system. In this system, fenitrothion was dissolved in acetone $(17 \mu \mathrm{l} / l)$ and the solution was supplied to a glass mixing chamber with tap water and connected to a perfusor pump (Gilson minipulse 3 ) that generated a constant solution flow of $\mathrm{I} .46 \mathrm{ml} / \mathrm{min}$ diluting to the desired concentration $(0.02$ and $0.04 \mathrm{mg} / \mathrm{l})$ by a constant water flow of $18 \mathrm{l} / \mathrm{hr}$, the outlet was connected to a 300-l glass test aquarium. In this way, the aqueous test solution was renewed approximately 3.6 times a day. Fortyeight hours before starting the experiences the system was connected to reach a balance of fenitrothion contaminated water. Every $24 \mathrm{hr}$ the fenitrothion mixture stock was renewed.

Eels were exposed to fenitrothion for a period of $96 \mathrm{hr}$. After 2, 8, 24, 48,56, 72 and $96 \mathrm{hr}$ four eels were removed, rinsed with tap water, anaesthetized with $100 \mathrm{mg} / l$ of MS222,6) weighted and dissected out quickly on an ice cold glass plate. Gill samples were removed quickly to analyze fenitrothion bioconcentrated. In a second experiment, eels previously exposed to fenitrothion during 96 -hr were rapidly transferred to a $300-l$ glass aquarium with a flow of $300 \mathrm{ml} / \mathrm{min}$ of clean tap water (recovery period) in the above described conditions but without toxicant. This system was maintained for $72 \mathrm{hr}$ more. At 12, 24, 48 and $72 \mathrm{hr}$ of experience four eels were removed. Gills were taken out and stored to further analyses of fenitrothion content and total protein determination.

Finally, another experiment was perfouned to test if the solvent (acetone) had any effect on branchial protein metabolism.

\section{Fenitrothion Residues Determination}

Gas chromatography analysis of the concentration used confirmed the presence of fenitrothion in the water over the entire exposure period. Water pesticide extraction was done based on the method of Zweigh and Sherma. ${ }^{7} \quad$ The determination of fenitrothion in the gill samples was carried out based on the mehtod of Richardson and Seiber ${ }^{8)}$ and adapted to our samples as following: gill tissue was liophylized and homogenized with $50 \%$ HCI $(0.01 \mathrm{ml})$ and $0.5 \%$ ethanol-ethyl acetate $(20$ $\mathrm{ml})$. This homogenate was centrifuged at $1200 \mathrm{rpm}(5$ min). After centrifugation a drop of $5 \%$ decanol in acetone was added to the supernatant. This mixture was dried on a rotatory vacuum evaporator. The dried residue was redissolved in $3 \mathrm{ml}$ of a mixture $1: 1$ cyclohexane-ethyl acetate and ultrasonized $(1 \mathrm{~min})$. Then, it was filtered throught a nylon filter ( $45 \mu \mathrm{m}$ diameter) by using a Varian Vac-elut. This volume was redissolved in $3: 1$ ethyl acetate-cyclohexane $(6 \mathrm{ml})$ and introduced in a Gas Permeation Chromatograph. The obtained eluated was dried and redissolved in ethyl acetate $(1 \mathrm{ml})$. This final volume was injected in a FISONS Instruments Gas Chromatograph equipped with a FPD 700 photometric detector and a SSL injector type. The detector and injector temperatures were 280 and $240^{\circ} \mathrm{C}$. Helium was used as gas carrier with a pressure of 145 $\mathrm{kPa}$. The detection limit was $<0.001 \mu \mathrm{g} / \mathrm{g}$. All solvents used were pesticide residue analysis grade. Fenitrothion recovery from gill samples was $>85 \%$.

\section{Pharmaco-kinetic Parameters}

A first-order one-compartment model was assumed to estimate the different pharmaco-kinetic parameters of fenitrothion in the branchial tissue ${ }^{9}$. One compartment model is useful, when an apparent steady-state is reached and all residues in the tissues are assumed to belong to a common pool, where they are equally available for depurationlo). In a steady-state situation, the bioconcentration factor (BCF) can be calculated from the ratio between the concentration of the chemical in the fish and the concentration in the water $\left(C_{\mathrm{f}} / C_{\mathrm{w}}\right)$. During the first part of the exposure period, elimination of the chemical can be neglected and the uptake rate constant $\left(K_{1}\right)$ can be calculated from: $K_{1}=C_{\mathrm{f}} /\left(C_{\mathrm{w}} \cdot t\right)$, where $t$ is the time. When the fish are transferred to clean water, the elimination rate constant $\left(K_{2}\right)$ can be derived from the slope of the first-order elimination equation ${ }^{11)}: \ln C_{\mathrm{f}}(t)=\operatorname{Ln} C_{\mathrm{f}}$ $(0)-K_{2} \cdot t$, where $C_{\mathrm{f}}(0)$ is the concentration of the chemi- 
cal in the fish at the beginning of the elimination period. The half-life of fenitrothion in the gill tissue was estimated according to the equation: $\mathrm{T}_{1 / 2}=-\ln 0.5 / K_{2}$.

\section{Total-Protein Determination}

Total proteins in gill tissue of animals exposed to fenitrothion were estimated by the method of Lowry et $a l .{ }^{11)}$ using the kit Protein assay Sigma Diagnostics ${ }^{\circledR}{ }^{\circ} \mathrm{P}$ 5656. Tissue homogenates were prepared in $0.1 \mathrm{M}$ phosphate buffer, $\mathrm{pH} 7.2$ at $0^{\circ} \mathrm{C}$, and centrifuged at $3500 \mathrm{rpm}$ (7 min). To the supernantant an equal volume of trichloroacetic acid was add to precipitate the soluble proteins and centrifugated at $3500 \mathrm{rpm}(10 \mathrm{~min})$. The supernatant was discharged and the pellet was dissolved in Lowry reagent solution $(1 \mathrm{ml})$. The tubes were kept at room temperature for $20 \mathrm{~min}$. Then Folin-phenol reagent was added $(0.5 \mathrm{ml})$, and the color after $30 \mathrm{~min}$ was read at $750 \mathrm{~nm}$ in a spectrophotometer against a reagent blank. Bovine serum albumin was used to construct the standard curve.

\section{Statistical Analysis}

Gills were analyzed individually, this gave a sample size of six gills for each exposure time. Mean values and standard deviations were calculated for each test group based on the values obtained for each individual gill tissue from six fishes. These values were compared by analysis of variance (ANOVA) and Duncan's multiple range test. All statistical analyses were performed on an IBM computer using SPSS + Programme. The significance level was set at 0.05 .

\section{RESULTS AND DISCUSSION}

As we can see in Table 1 the bioaccumulation of fenitrothion in eel gills was apparent after exposure to both pesticide concentrations. The results showed a linear correlation $(r=0.8)$ between the exposure concentration and the bioconcentrated fenitrothion in gills of the european eel until the steady-state was reached. Bioaccumulation was higher in those animals exposed to the highest pesticide concentration. The rapid fenitrothion accumulation observed was in agreement with those works reported by several authors in other fish species. ${ }^{9,12-13,15)}$

An uptake rate constant $\left(K_{1}\right)$ of $0.037 \mathrm{ml} \mathrm{g}^{-1} \mathrm{hr}^{-1}$ was calculated from the data set obtained in the experiment with $0.02 \mathrm{ppm}$ of fenitrothion. This value was bigger when the animals were exposed to $0.04 \mathrm{ppm}\left(0.058 \mathrm{ml} \mathrm{g}^{-1}\right.$ $\mathrm{hr}^{-1}$ ) and this would be related with the less time required to reach the steady-state (Table 2). That fact denotes, the fate that OP insecticides bioaccumulate in fish tissues depending on their properties but also on the type of organism or tissue, physiological condition and environmental factors as for example water concentration. BCF and internal bioconcentration factor (IntBCF) calculated in this study were quite similar from both experiments (Table 2). This could mean that a balance was reached between the fenitrothion concentration in the blood and in the water during the uptake phase. The highest $K_{1}$ during exposure to $0.04 \mathrm{ppm}$ induced an earliest steady-state. So, after $24 \mathrm{hr}$ a plateau was reached and thereafter it was maintained during the rest of the exposure period (Fig. 1). That fact, may lead to high accumulation rates in organs highly irrigated as brain or liver. Similar values of BCF and IntBCF where observed in other fish species as Cyprinus carpio exposed to different compounds. ${ }^{15)}$

The constant sublethal concentration of fenitrothion in the surrounding water during $96 \mathrm{hr}$ appears to be physiologically stressful to the european eel. The most obvious sign of fenitrothion intoxication was retlessness, erratic swimming, convulsions and lost of balance, some

Table 1 Fenitrothion content $(\mu \mathrm{g} / \mathrm{g})$ in gills of the eel (Anguilla anguilla) during the exposure to fenitrothion in a flow-through test system and after the recovery period.

\begin{tabular}{cll}
\hline Time $(\mathrm{hr})$ & $0.02 \mathrm{ppm}$ & $0.04 \mathrm{ppm}$ \\
\hline \multicolumn{3}{c}{ Exposure period } \\
2 & $0.006 \pm 0.000$ & $0.470 \pm 0.110$ \\
8 & $0.009 \pm 0.006$ & $0.530 \pm 0.010$ \\
$\mathbf{2 4}$ & $0.017 \pm 0.007$ & $\mathbf{1 . 7 0 5} \pm \mathbf{0 . 1 0 5}$ a) \\
$\mathbf{4 8}$ & $\mathbf{0 . 0 3 3} \pm \mathbf{0 . 0 1 5}$ a) & $\mathbf{1 . 3 0 5} \pm \mathbf{0 . 7 2 5}$ \\
$\mathbf{5 6}$ & $\mathbf{0 . 0 2 7} \pm \mathbf{0 . 0 1 2}$ & $\mathbf{1 . 0 5 5} \pm \mathbf{0 . 0 6 5}$ \\
$\mathbf{7 2}$ & $\mathbf{0 . 0 2 3} \pm \mathbf{0 . 0 0 6}$ & $\mathbf{1 . 7 6 3} \pm \mathbf{0 . 4 2 9}$ \\
$\mathbf{9 6}$ & $\mathbf{0 . 0 3 3} \pm \mathbf{0 . 0 0 6}$ & $\mathbf{1 . 4 4 5} \pm \mathbf{0 . 8 2 8}$ \\
& Recovery period & \\
104 & $0.057 \pm 0.006$ & $1.740 \pm 0.430$ \\
108 & $0.030 \pm 0.010$ & $0.855 \pm 0.050$ \\
120 & $0.025 \pm 0.005$ & $1.365 \pm 0.475$ \\
144 & $0.023 \pm 0.002$ & $0.485 \pm 0.125$ \\
168 & $0.030 \pm 0.011$ & $0.175 \pm 0.035$ \\
\hline
\end{tabular}

a) Bold $=$ steady-state.

Table 2 Fenitrothion pharmacokinetics in the gills of the european eel (Anguilla anguilla).

\begin{tabular}{ccccccc}
\hline & $\begin{array}{c}K_{1} \\
\left(\mathrm{ml} \mathrm{g}^{-1} \mathrm{hr}^{-1}\right)\end{array}$ & $\begin{array}{c}\text { Steady-state } \\
(\mathrm{hr})\end{array}$ & BCF $\left.{ }^{\mathrm{a}}\right)$ & IntBCF & $\begin{array}{c}K_{2} \\
\left(\mathrm{hr}^{-1}\right)\end{array}$ & $\begin{array}{c}T_{1 / 2} \\
(\mathrm{hr})\end{array}$ \\
\hline $0.02 \mathrm{ppm}$ & 0.037 & $48-96$ & 1.65 & 0.524 & 0.0014 & 495 \\
$0.04 \mathrm{ppm}$ & 0.058 & $24-96$ & 36.36 & 34.77 & 0.029 & 23.90 \\
\hline
\end{tabular}

a) Bioconcentration factor. 


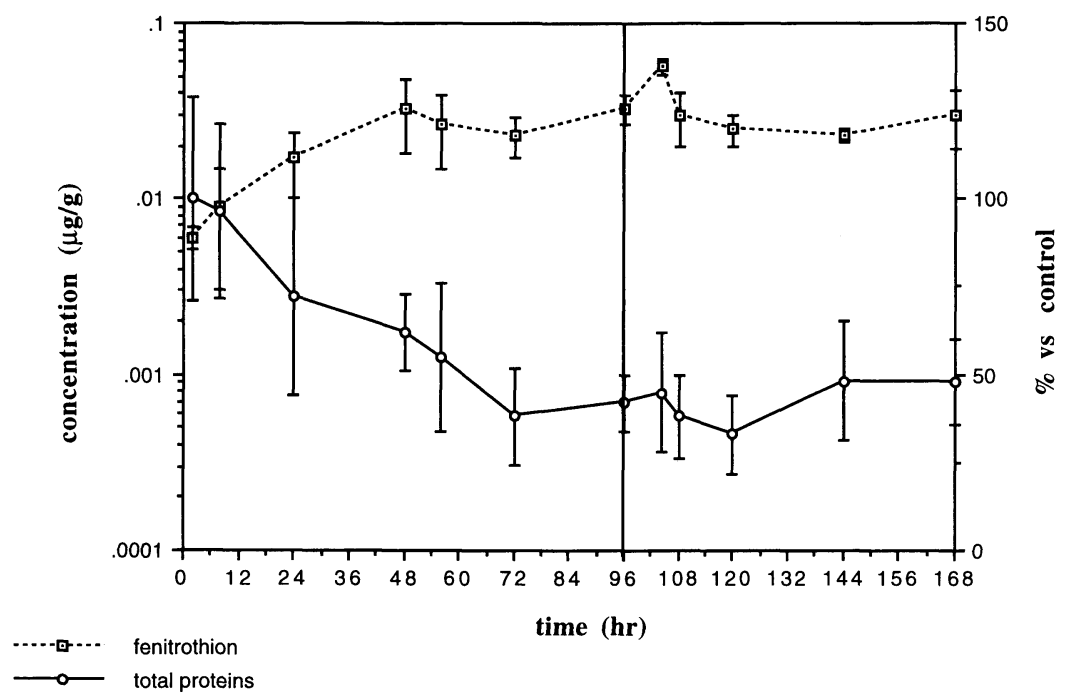

Fig. 1 Fenitrothion content $(\mu \mathrm{g} / \mathrm{g})$ and total protein levels (\%) compared to controls in the gills of the european eel during a 96 hr exposure to $0.02 \mathrm{ppm}$ of fenitrothion in a flow-through system and after transferred to clean water.

Table 3 Total protein content (mg/g) in gills of the eel (Anguilla anguilla) during the experiments.

\begin{tabular}{cccc}
\hline \multirow{2}{*}{$\begin{array}{c}\text { Time } \\
(\mathrm{hr})\end{array}$} & $\begin{array}{c}\text { Acetone }^{\mathrm{b}} \mathrm{c} \\
17 \mu \mathrm{l} / \mathrm{l}\end{array}$ & $0.02 \mathrm{ppm}^{\mathrm{b})}$ & $0.04 \mathrm{ppm}$ \\
\cline { 3 - 4 } & \multicolumn{3}{c}{ Contaminated water } \\
0 & $12.78 \pm 1.96$ & $17.29 \pm 5.10$ & $37.12 \pm 9.26$ \\
2 & $10.75 \pm 3.19$ & $16.62 \pm 4.34$ & $26.59 \pm 5.53$ \\
8 & $14.41 \pm 4.17$ & $12.47 \pm 4.90^{\text {a) }}$ & $18.00 \pm 7.39^{\text {a) }}$ \\
24 & $17.50 \pm 4.43$ & $9.37 \pm 3.74^{\text {a) }}$ & $12.74 \pm 4.22^{\text {a) }}$ \\
48 & $15.16 \pm 4.01$ & $7.19 \pm 1.41^{\text {a) }}$ & $12.44 \pm 1.93^{\text {a) }}$ \\
56 & $14.85 \pm 1.44$ & $7.98 \pm 2.95^{\text {a) }}$ & $10.28 \pm 1.25^{\text {a) }}$ \\
72 & $16.74 \pm 5.08$ & $6.64 \pm 2.09^{\text {a) }}$ & $10.27 \pm 3.39^{\text {a) }}$ \\
96 & $14.40 \pm 5.16$ & $5.76 \pm 1.96^{\text {a) }}$ & $10.13 \pm 2.98^{\text {a) }}$ \\
& & Clean water $^{\text {a) }}$ & \\
104 & $10.51 \pm 1.51$ & $8.25 \pm 3.00^{\text {a) }}$ & $6.42 \pm 3.07^{\text {a) }}$ \\
108 & $12.87 \pm 4.19$ & $8.20 \pm 0.21^{\text {a) }}$ & $10.76 \pm 2.41^{\text {a) }}$ \\
120 & $13.90 \pm 2.76$ & $10.35 \pm 3.64^{\text {a) }}$ & $12.15 \pm 3.93^{\text {a) }}$ \\
144 & $15.83 \pm 4.12$ & $11.04 \pm 4.48^{\text {a) }}$ & $11.18 \pm 3.89^{\text {a) }}$ \\
168 & $13.93 \pm 4.87$ & $12.85 \pm 5.12^{\text {a) }}$ & $16.24 \pm 4.02^{\text {a) }}$ \\
\hline
\end{tabular}

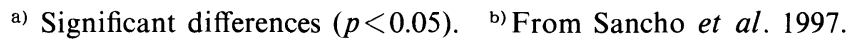

of the experimental fishes showed diminished motor and sensory activity but all of them survived the estipulated exposure period. These symptoms had been reported in the european eel under sublethal exposure to other organophosphate insecticides. ${ }^{16-18)}$

Total protein content on branchial tissue of the eels exposed to the solvent (acetone) did not show any significant difference $(p>0.05)$ from control animals as was previously reported. ${ }^{20)}$ However, fish exposed to fenitrothion showed a significant $(p<0.05)$ depletion in total proteins. This depletion in protein content was observed throughout the exposure period (Table 3, Fig. 2). A maximun depletion was observed after $8 \mathrm{hr}$ of exposure and was constantly maintained until the end of the exposure. These findings were related with the duration of the steady-state for fenitrothion into branchial tissue of the eels (Tables 1 and 2). We found a good linear correlation $(r=0.9)$ between fenitrothion bioconcentration and protein depletion in eel gill tissue during the uptake period in animals exposed to $0.04 \mathrm{ppm}$ and this correlation was maintained until the $96 \mathrm{hr}$ exposure. A $70 \%$ of reduction was observed in total proteins of the gills after $96 \mathrm{hr}$. Total protein depletion was also observed in gill tissue during the exposure of the animals to $0.02 \mathrm{ppm}$ of fenitrothion as was reported in a previous work. ${ }^{19)}$ Comparing pesticide bioconcentration during the exposure to $0.02 \mathrm{ppm}$ with the results obtained in this work, a good correlation between both also occurs $(r=$ 


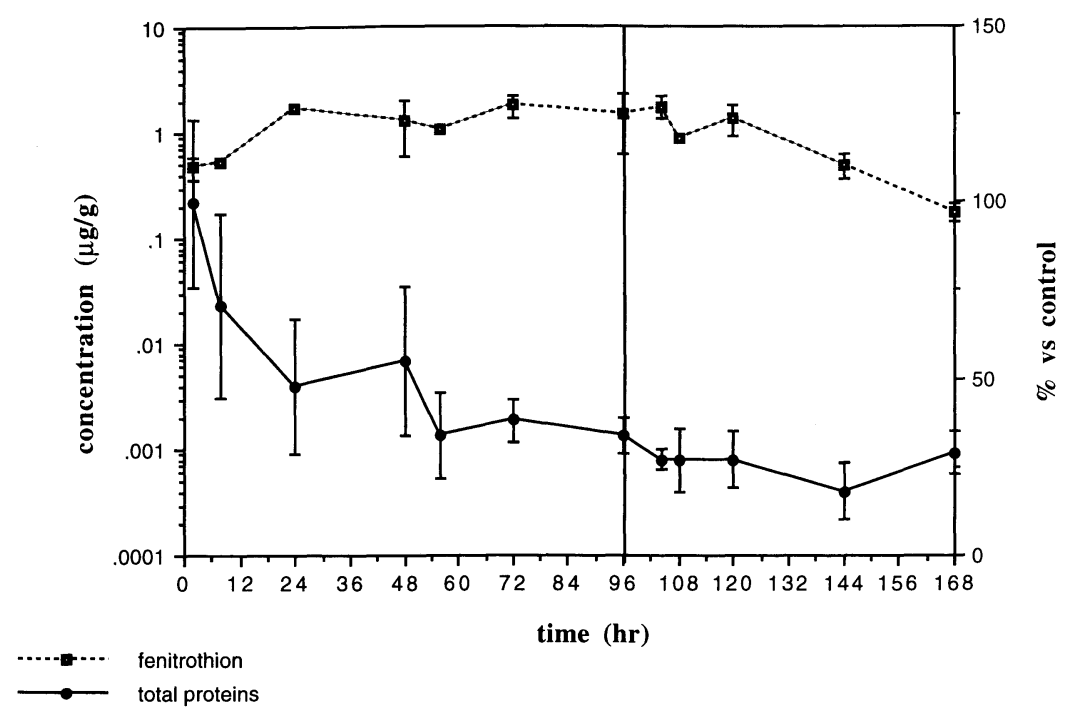

Fig. 2 Fenitrothion content $(\mu \mathrm{g} / \mathrm{g})$ and total protein levels (\%) compared to controls in the gills of the european eel during a 96 hr exposure to $0.04 \mathrm{ppm}$ of fenitrothion in a flow-through system and after transferred to clean water.

0.9). So we can assume the same behaviour for fenitrothion during the exposure period to both fenitrothion concentrations. A similar decrease in total proteins in branchial tissue was reported previously in other fish species exposed to several pesticides. ${ }^{20,21)}$

A reduction in the total protein content indicates that tissue proteins may undergoes proteolysis which results in the production of free amino acids used in the TCA cycle for energy production during stress conditions. ${ }^{21)}$ But also for tissue regeneration and compensatory production of enzymes lost as a result of cellular damage or enzyme induction in an effort to detoxify the pesticide. ${ }^{22)}$ In fact, proteins are the major energy resources in fish. ${ }^{23)}$ It is known the capacity that the european eel has to mobilizate and metabolizate proteins for glucose resource under starvation situations before use glycogen stores. ${ }^{24)}$ Fish with a trophic/migratori live-cycle have strong tendency to protect stored glycogen in liver and muscle until a physiological metamorphose appears from a steady to another. ${ }^{25)}$

A rapid tendency to the elimination of the toxicant accumulated was observed when the animals were transferred to clean water. A passive elimination may be done across the gills by the same partitioning process involved in the uptake, owing to their physical characteristics. ${ }^{10)}$ Elimination of bioconcentrated fenitrothion from branchial tissue could be explained by a one-compartment first-order kinetic process (Table 2) with a $K_{2}$ of $0.029 \mathrm{hr}^{-1}$ confirming its rapid tendency to elimination. That would be related with a low half-life in the gill tissue $(23.90 \mathrm{hr})$ during the experiment with $0.04 \mathrm{ppm}$ of toxicant. Although this toxicant was detected during the entire depuration phase, a reduction of $88 \%$ was reached at the end of the test confirming the ability of the parent compound to cross branchial barrier in both directions water/blood and indicating that the elimination would be also limited. That could explain the lowest value of $K_{2}$ and the highest half-live of fenitrothion in gills during the experiment with $0.02 \mathrm{ppm}$ (Table 2).

Presence of fenitrothion in gills of the eel during the recovery period would indicate a branchial elimination of the toxicant from the organs via blood. That in fact provides availability for metabolization or excretion of fenitrothion coming from organs with a high pesticide "affinity" as brain, as well as highly irrigated. ${ }^{26)}$ This tendency to eliminate fenitrothion via gills could be related directly with a protection of the animals against many transformation products. Fenitrothion metabolites, as fenitro-oxon, are known as even more toxic than the parent compound. ${ }^{27)}$ Our results are in agreement with those found by Dauble and Curtis ${ }^{28)}$ who found a rapid branchial elimination of dietary quinoline by the fish Salmo gairdneri, showing the branchial excretion as primary route of excretion because all of the other possible routes of elimination contributed to $<5 \%$ of the total eliminated dose.

As indicated by $\mathrm{Nimmo}^{29)}$ various organs apart liver can be involved in elimination process as gills, kidneys and integument. Althought some fish species appears to eliminate pesticides through biliary excretion while others eliminate those compounds primarily through branchial excretion. Differences in detoxification systems occurs among species, the physico-chemical properties of the insecticide should act allowing and supplying some detoxification routes. ${ }^{30}$ )

Other fish species show a high tendency to eliminate fenitrothion. ${ }^{31)}$ These authors ajusted the elimination of 
the bioconcentrated fenitrothion in the fish Poecilia reticulata to a first-order, one-compartment model; in that case a $K_{2}$ of $0.047 \mathrm{hr}^{-1}$ was calculated for this insecticide in the full organism, indicating that a rapid elimination of fenitrothion had been done. Moreover, these authors suggested that in vivo biotransformation occured at a rate that was relatively slower than the elimination rate of the parent compound. Elimination of fenitrothion from fish tissues also seems be not influenced by the presence in a mixture with other organophosphates. ${ }^{13)}$ On the other hand, as indicated Dauble and $\mathrm{Curtis}^{28)}$ rapid excretion of a xenobiotic by fish can occurs across the gills because this organ has a high surface area, receives the entire cardiac output, and is ventilated by large volumes of water. Other teleost excretory routes are more limited in their ability to rapidly excrete xenobiotics because they are dependent upon active processes.

During recovery period a tendency to recuperate total protein levels in branchial tissue was observed (Table 2, Fig. 2). At the end of this period, recovery of protein content was upon 50\%. These data are in agreement with those found in the eel exposed to $0.02 \mathrm{ppm} .{ }^{19)}$ In that work, authors reported metabolic disorders during the exposure to the toxicant however they did no persist when the fish were transferred to clean water. Those findings are very important in evaluations of the ecotoxic potential of pesticides in the aquatic environment and of possible implications for fish populations. Data obtained from fenitrothion bioconcentration in the european eel bring information about real situation in the important branchial tissue. However, in both cases, the authors are unable to correlate these findings due to a lack of information in the literature regarding the recovery aspect. Although morphological and structural damage were not estimated in the present study, it is known the ability of OP as other pesticides to cause lesions in the gills of exposed fish, including hypertrophy, hyperplasia, edema and necrosis ${ }^{32)}$; a study of the gill ATPase activity, paralelly to the present work, showed how fenitrothion induced a significant inhibiton of both $\mathrm{Mg}^{2+}$ and $\mathrm{Na}^{+} \mathrm{K}^{+}$ATPase activities in branchial tissue and a tendency to recover the normal function was observed when a recovery period was allowed ${ }^{33)}$.

In summary, fenitrothion show to be rapidly pass branchial barrier and a high tendency to bioconcentrate in it but, in the same way, eels showed a high capacity to eliminate this toxicant across gills. The constant depuration of parent fenitrothion from gills could suggest a low biotransformation rate. Gill bioconcentration produced an eel stress situation and then, a protein depletion parallely to fenitrothion uptake. When a steady-state was reached for the toxicant a tendency to stop depletion also was observed. During the entire recovery period metabolism tendency was to recuperate total protein levels for regeneration and repair of damaged tissue, and restored energy and normal function in gills. That would allow survival of the animals in the nature if concentrations of fenitrothion rest in the water after spray operation.

\section{ACKNOWLEDGMENTS}

Authors wish to thank A. Ten and C. Lleó from Agrarian Laboratory of Generalitat Valenciana for their help in the analysis of the samples. This work was suported by a grant (AMB961118-CO1) from the Comisión Interministerial de Ciencia $y$ Tecnología (CICYT) del Ministerio de Educación y Ciencia, Spain and a grant ( $G V-D-A G-01-154-96)$ from Conselleria de Educación y Ciencia (Generalitat Valenciana), Spain.

\section{REFERENCES}

1) P. Mineau: "Cholinesterase-Inhibiting Insecticides," Vol. 2, Elsevier, Amsterdam, 1991

2) G. H. Hugges: "Fish Physiology," ed. by W. S. Hoar, D. J. Randall and J. D. Brett, Vol. X, Academic Press, Orlando, 1984

3) W. J. A. Van den Heuvel, A. D. Forbis, B. A. Halley, C. C. $\mathrm{Ku}, \mathrm{T}$. A. Jacob \& P. G. Wislocki: Environ. Toxicol. Chem. 15, 2263 (1996)

4) S. Lacorte \& D. Barceló: Environ. Sci. Technol. 28, 1159 (1994)

5) M. J. Morgan, L. L. Fancey \& J. W. Kiceniuk: Can. J. Fish. Aquat. Sci. 47, 1652 ( 1990)

6) M. D. Ferrando, E. Sancho \& E. Andreu-Moliner: $J$. Environ. Sci. Health B26, 491 (1991)

7) G. Zweigh \& J. Sherma: Anal. Methods Pestic. Plant Growth Regulat. 6, 132 (1972)

8) E. Richardson \& J. N. Seiber: J. Agric. Food Chem. 41, 416 (1993)

9) T. Tsuda, S. Aoki, M. Kojima \& H. Harada: Toxicol. Environ. Chem. 24, 185 (1989)

10) G. M. Rand \& S. R. Petrocelli: "Fundamentals of Aquatic Toxicology," Hemisphere Publising Corporation, Washington (1985)

11) O. H. Lowry, N. J. Rosebrough, A. L. Farr \& R. J. Randall: J. Biol. Chem. 193, 265 (1951)

12) T. Tsuda, S. Aoki, M. Kojima \& H. Harada: Comp. Biochem. Physiol. 96C, 23 (1990)

13) T. Tsuda, S. Aoki, T. Inoue \& M. Kojima: Water Res. 29, 455 (1995)

14) J. De Bruijn \& J. Hermens: Environ. Toxicol. Chem. 10, 791 (1991)

15) G. Gluth, D. Freitag, W. Hanke \& F. Korte: Comp. Biochem. Physiol. 81C, 273 (1985)

16) H. C. Da Silva, H. S. G. Medina, E. Fanta \& M. Bacila: Comp. Biochem. Physiol. 105C, 197 (1993)

17) E. Sancho, M. D. Ferrando, M. Gamón \& E. AndreuMoliner: Biomed. Environ. Sci. 44, 416 (1994)

18) J. Cerón, E. Sancho, M. Ferrando, C. Gutierrez \& E. Andreu-Moliner: J. Environ. Sci. Health B31, 1029 (1996)

19) E. Sancho, M. D. Ferrando \& E. Andreu-Moliner: Ecotoxicol. Environ. Safety 36, 57 (1997)

20) P. Baskaram \& S. Palanichamy: J. Ecobiol. 2, 97 (1990)

21) P. Baskaram, G. Gapalakrishnasamy \& P. G. Sathiyabama: J. Ecotoxicol. Environ. Monit. 1, 31 (1991) 
22) T. S. Gill, T. Pande \& H. Tewari: Ecotoxicol. Environ. Safety 21, 80 (1991)

23) J. D. Brett \& D. D. Groves: "Fish Physiology", Vol. III, ed. by W. S. Hoar, D. J. Randall and J. D. Brett, Academic Press Inc., Orlando, pp. 280-344, 1979

24) S. Hayashi \& Z. Ooshiro: Nippon Suisan Gakkaishi 41, 791 (1975)

25) S. Barni, G. Bernocchi \& G. Gerzeli: Tissue Cell. 17, 97 (1985)

26) E. Sancho, M. D. Ferrando \& E. Andreu-Moliner: $J$. Environ. Sci. Health B32, 901 (1997)

27) K. Kobayashi, Y. Nakamura \& N. Imada: Bull. Jpn. Soc. Sci. Fish 51 , 599 (1985)

28) D.D. Dauble \& L. R. Curtis: Can. J. Fish. Aquat. Sci. 46, 705 (1989)

29) I. A. Nimmo: "Fundamentals of Aquatic Toxicology," ed. by G. M. Rand and S. R. Petrocelli, Hemisphere Publising Corporation, Washington, pp. 335-373, 1985

30) J. De Bruijn, W. Seinen \& J. Hermens: Environ. Toxicol. Chem. 12, 1041 (1993)

31) J. De Bruijn \& J. Hermens: Aquat. Toxicol. 24, 257 (1993)

32) N. Areechon \& J. A. Plumb: Bull. Environ. Contam. Toxicol. 44, 435 (1990)

33) E. Sancho, M. D. Ferrando \& E. Andreu-Moliner: Ecotoxicol. Environ. Safety 38, 132 (1997)
要約

ウナギのェラにおけるフェニトロチオンの消長

E. サンチョ, M. D. フェルランド

M. ガモン, E. アンドリュー

ウナギ (Anguilla anguilla) を致死濃度以下のフェニトロ チオン (以下薬物) を溶解した流水試験系に放ち, 生物濃 縮および排泄を調べた. $0.02 \mathrm{ppm}$ 区で $48 \mathrm{hr}$ 後, $0.04 \mathrm{ppm}$ 区 で $24 \mathrm{hr}$ 後にそれぞれ安定状態になった. 生物濃縮係数は $0.04 \mathrm{ppm}$ 区で大きかった. ウナギを清浄水に移すと速やか に薬物を排泄した。ウナギのエラにおける薬物動態パラ メーター, $K_{1}, K_{2}, T_{1 / 2}$ を算出したところ, $0.02 \mathrm{ppm}, 0.04$ $\mathrm{mmp}$ 区でそれぞれ $K_{1}: 0.037,0.058 \mathrm{ml} \mathrm{g}^{-1} \mathrm{hr}^{-1} ; K_{2}$ : $0.0014,0.029 \mathrm{hr}^{-1} ; T_{1 / 2}: 495,23.9 \mathrm{hr}$ であった. 並行して総 タンパク濃度を調べたところ， $0.04 \mathrm{ppm}$ 区で $9.6 \mathrm{hr}$ 後に 70\%減少していた. タンパク濃度の回復傾向は清浄水に移 された後みられたが，その程度は大きくなかった。これら の結果から，薬物に接触するというストレス状態がウナギ のエラにおけるエネルギー要求に応じてタンパクの利用を 必要とすることが示唆された。 